\title{
Behavior of the Use of Mosquito Net as a Prevention of Malaria in Ondorea Village, Nanga Panda Sub-district
}

\author{
Yustina PM Paschalia * (D), Anatolia K. Doondori ${ }^{1} \mathbb{D}$, Irfan $\operatorname{Irfan}^{1}$ (D) , Norma Tiku Kambuno ${ }^{2}$ (D) \\ ${ }^{1}$ Department of Nursing, Poltekkes Kemenkes Kupang, Kupang, Indonesia; ${ }^{2}$ Department of Medical Laboratory Technology, \\ Poltekkes Kemenkes Kupang, Kupang, Indonesia
}

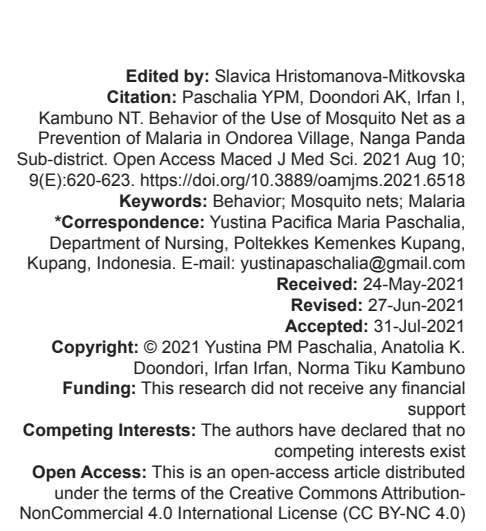

NonCommercial 4.0 of the Creative Commons Attribution-

\begin{abstract}
BACKGROUND: Malaria is an infectious disease that is still a world public health problem, especially in developing countries with tropical climates, including Indonesia. Ondorea Village in Nangapanda Subdistrict, Ende Regency, is one of the villages in East Nusa Tenggara, which is a province with academic performance indicators (APIs) above the national average.

AIM: The objective of the study is to determine family behavior in using mosquito nets as an effort to prevent malaria in Ondorea Village, Nangapanda District.

METHODS: This research is a survey research type with descriptive research design, the design used is "cross sectional". The population were all families residing in Ondorea Village, totaling 178 families, the sample in this study used a total sample. The variable in this study was a single variable, namely, family behavior in the use of mosquito nets. The data used in this study are primary data collected by making home visits.

RESULTS: Public knowledge about the use of mosquito nets as an effort to prevent malaria in Ondorea Village Nangapanda District was in the sufficient category, namely, $85.39 \%$, those with good knowledge of $6.34 \%$ and those with moderate knowledge of $7.87 \%$. The public attitude about the use of mosquito nets is in a good category, namely, $99.4 \%$, which has a sufficient attitude of $0.56 \%$.

CONCLUSION: There is no relationship between the level of knowledge and the behavior of using mosquito nets, but it is found that there is a relationship between family attitudes and the behavior of using mosquito nets as an effort to prevent malaria.
\end{abstract}

\section{Introduction}

Malaria is an infectious disease that is still a public health problem in the world, especially in developing countries with tropical climates, including Indonesia [1]. This disease affects the high mortality rate for infants, toddlers, and pregnant women [2]. In addition, malaria directly causes anemia and can reduce work productivity [3]. The World Malaria Report in 2011 states that malaria occurs in 106 countries and infects 3.3 billion of the world's population who live in areas at risk of contracting malaria [4]. The incidence of malaria in Indonesia has shown a decline, namely 4.10 in 2005 to 1.38 in 2013 [5]. The incidence of malaria in Ondo Rea Village, Nangapanda District in 2017 was $24 \%$ and in 2018 was $8 \%$. Insecticide-treated mosquito nets have been distributed to every family (Puskesmas Nangapanda, 2018) [6]. In its use, there are still families who say that the mosquito nets they received were not used at nighttime, some even used it as a hedge.

The national prevalence of malaria based on the 2013 Riskesdas was $0.6 \%$ where the provinces with academic performance indicator (API) above the national average were West Nusa Tenggara, Maluku, North Maluku, Central Kalimantan, Bangka Belitung, Kepulauan Riau, Bengkulu, Jambi, Central Sulawesi, Gorontalo, and Aceh [7], [8]. The highest prevalence rates were found in eastern Indonesia, namely in West Papua (10.6\%), Papua (10.1\%), and East Nusa Tenggara (4.4\%). Ondorea Village in Nangapanda Subdistrict, Ende Regency is one of the villages in East Nusa Tenggara which is a province with APIs above the national average [7], [9].

Efforts to reduce morbidity and mortality are carried out through the malaria eradication program, whose activities include early diagnosis, prompt and precise treatment, as well as vector surveillance and control in terms of public education and an understanding of environmental health, all of which are aimed at breaking the chain of malaria transmission [10], [11]. The government's efforts to reduce morbidity and mortality are through a malaria eradication program with early diagnosis and prompt and appropriate treatment, vector control, and control in order to break the chain of malaria transmission [12], [13]. Control is also carried out using chemical, biological, environmental management, and integrated control. In the National 
Medium Term Development Plan (NMTDP), malaria control indicators reduce the malaria morbidity rate to below 1/1,000 population, so that Indonesia will be free of malaria by 2030 [14], [15].

Malaria control that is currently being carried out in Indonesia is an integrated control, namely a combination of several methods including vector control, preventive therapy, diagnostic tests, treatment with artemisinin-based combination therapy (ACT), and strengthening surveillance [5], [9]. Vector control is carried out by taking approaches and considerations according to the environmental needs of the local community. Integrated control through vector control aims to reduce contact between humans and vectors and protect humans from the bites of mosquitoes infected with the malaria parasite. One of the efforts to protect against mosquito bites is the use of a mosquito net, the use of a mosquito net is a form of community participation in efforts to prevent malaria transmission that is personal protection [16], [17].

The distribution and use of insecticide-treated nets, especially Long Lasting Insecticidal Nets (LLINs) are one of the main interventions considered effective in malaria prevention and control recommended by the WHO with the aim of achieving the Millennium Development Goals target [5], [18], [17]. Insecticidetreated mosquito nets can also be an alternative for malaria vector control in areas where people reject the indoor residual spraying method or it can be an additional effort to prevent malaria transmission [17]. The distribution of LLINs in Indonesia has been carried out since 2006, while the free treatment using ACT has been carried out since 2004 [17].

One of the preventive measures for malaria that is still being implemented is to use insecticidetreated mosquito nets or polishing mosquito nets, as recommended by the WHO from November 2004. Insecticides used in mosquito nets are safe for humans and have been used by many countries [19]. The insecticide-treated mosquito net program is an alternative for malaria vector control in areas where mosquitoes bite inside the house. The use of insecticidetreated mosquito nets can also be an additional effort to prevent malaria transmission using insecticide-treated mosquito nets [17].

The district government of Ende targets that by 2022, malaria will be eliminated, this is a joint commitment that has been stated in the NMTDP. The research objective was to determine family behavior in using mosquito nets as an effort to prevent malaria in Ondorea Village, Nangapanda District. The specific objectives of this study were to identify knowledge and attitudes of the family about malaria in the use of mosquito nets, further identifying the relationship between knowledge, family attitudes with family behavior in using mosquito nets. It is hoped that the results of this study can provide an overview of family behavior in using mosquito nets as an effort to prevent malaria so that it can be an input for health workers in implementing health promotion programs.

\section{Methods}

This research was a descriptive survey research with a "cross sectional" design. The sample in this study were all families in the Ondorea Village area, amounting to 178 families. The location was Ondorea Village, Nangapanda District, which was held in August - October 2019.

The instrument used was a questionnaire, data collected in the form of primary data were obtained from interviews. Before analyzing the collected data, it was processed manually, namely Editing (checking data), coding (coding), data entry (entering data), and tabulating (tabulating). Data analysis used descriptive analysis, for the knowledge questionnaire, each question was given a value of 1 if the respondent answered correctly, and 0 if the answer was wrong. The attitude questionnaire was given a score of 1 if the answer is yes, and 0 if the answer is no, likewise the behavior questionnaire was given a score of 1 if it answers yes, and 0 if it answers no. The next assessment was determined by the categories: Good $=75-100 \%$, Enough $=50-74 \%$, Less $=<50 \%$. Furthermore, the results were analyzed using the Chi-square statistical test to analyze the relationship between knowledge and attitudes toward family behavior in the use of mosquito nets.

This research has received ethical permission from the Research Ethics Commission of Poltekkes Kemenkes Kupang with Number LB.02.03/1/0009/2019 dated July 26, 2019, all respondents were asked for willingness by signing an informed consent.

\section{Results}

Table 1 shows that the majority of household respondents are male, $84.2 \%$, age $>39$ years as much as $60.67 \%$, junior high school education as much as $46.6 \%$, work is dominated by farmers, $74.1 \%$, and family income $>$ Rp. 1,000,000 $83.14 \%$ and the number of family members $>4$ people is $70.9 \%$.

Table 2 shows that the level of family knowledge is at a sufficient criterion of $85.39 \%$ with community behavior in good criteria of $80.3 \%$. The results of the analysis showed a $p>0.05(0.007)$, meaning that there was no relationship between the level of knowledge and family behavior.

Table 3 shows that family attitudes are in good criteria, namely $99.4 \%$ and family behavior is in good criteria 
Table 1: Characteristics of respondents

\begin{tabular}{|c|c|c|}
\hline Characteristics & $\mathrm{n}$ & $\%$ \\
\hline \multicolumn{3}{|l|}{ Gender } \\
\hline Male & 150 & 84.2 \\
\hline Female & 28 & 15.7 \\
\hline \multicolumn{3}{|l|}{ Age } \\
\hline 19-29 years old & 20 & 11.23 \\
\hline $30-38$ years old & 50 & 28.0 \\
\hline$\geq 39$ years old & 108 & 60.67 \\
\hline \multicolumn{3}{|l|}{ Education } \\
\hline Elementary & 39 & 22.0 \\
\hline Junior High & 83 & 46.6 \\
\hline High school & 48 & 27.0 \\
\hline College & 8 & 4.5 \\
\hline \multicolumn{3}{|l|}{ Occupation } \\
\hline Farmer & 132 & 74.1 \\
\hline Civil servants & 32 & 18.0 \\
\hline Private/Employee & 14 & 2.24 \\
\hline \multicolumn{3}{|l|}{ Family Income } \\
\hline$>$ Rp. $1,000,000$ & 148 & 83.14 \\
\hline$<$ Rp. $1,000,000$ & 30 & 16.85 \\
\hline \multicolumn{3}{|c|}{ Number of Family Members } \\
\hline 1-4 people & 52 & 29.21 \\
\hline$>4$ person & 126 & 70.9 \\
\hline Total & 178 & 100 \\
\hline
\end{tabular}

$80.3 \%$. Further analysis showed that the $p<0.05(0.000)$ means that there is a relationship between attitude and the behavior of using mosquito nets.

Table 2: The relationship between knowledge and the behavior of using mosquito net Ondorea village, Nanga district

\begin{tabular}{|c|c|c|c|c|c|c|c|c|c|}
\hline \multirow[t]{3}{*}{ Knowledge } & \multicolumn{6}{|c|}{ Behavior } & \multirow{2}{*}{\multicolumn{2}{|c|}{ Total }} & \multirow[t]{3}{*}{$p$-value } \\
\hline & \multicolumn{2}{|c|}{ Good } & \multicolumn{2}{|c|}{ Enough } & \multicolumn{2}{|c|}{ Moderate } & & & \\
\hline & $\mathrm{n}$ & $\%$ & $\mathrm{n}$ & $\%$ & $n$ & $\%$ & $n$ & $\%$ & \\
\hline Good & 8 & 4.4 & 3 & 1.6 & 1 & 0.5 & 12 & 6.74 & 0.07 \\
\hline Enough & 133 & 74.7 & 19 & 10.6 & 0 & 0 & 152 & 85.39 & \\
\hline Less & 2 & 1.1 & 11 & 6.1 & 1 & 0.5 & 14 & 7.87 & \\
\hline Total & 143 & 80.3 & 33 & 18.5 & 2 & 1.1 & 178 & 100 & \\
\hline
\end{tabular}

\section{Discussion}

Malaria is an infectious disease that results from the interaction of hosts, parasites, and the environment. This disease is contagious, caused by parasites of the genus Plasmodium which are included in the protozoan group through a puncture (bite) of the Anopheles spp mosquito that lives and reproduces in humans red blood cells. There are several types of malaria parasites, namely Plasmodium falciparum, which causes malaria tertiana maligna; Plasmodium vivax, which causes malaria tertiana benigna; Plasmodium malariae, which causes malaria quartana; and Plasmodium ovale, which causes malaria ovale [20], [21]. Also, Plasmodium knowlesi has a malaria rate that is quite severe, reaching $8 \%$ [22].

Table 3: The relationship of family attitudes toward mosquito net use behavior in Ondorea Village, Nanga District

\begin{tabular}{|c|c|c|c|c|c|c|c|c|c|}
\hline \multirow{3}{*}{$\begin{array}{l}\text { Family } \\
\text { Attitudes }\end{array}$} & \multicolumn{6}{|c|}{ Behavior } & \multirow{2}{*}{\multicolumn{2}{|c|}{ Total }} & \multirow[t]{3}{*}{$p$-value } \\
\hline & \multicolumn{2}{|c|}{ Good } & \multicolumn{2}{|c|}{ Enough } & \multicolumn{2}{|c|}{ Moderate } & & & \\
\hline & $\mathrm{n}$ & $\%$ & $\mathrm{n}$ & $\%$ & $n$ & $\%$ & $\mathrm{n}$ & $\%$ & \\
\hline Good & 142 & 79,8 & 33 & 18.5 & 2 & 1.1 & 177 & 99.4 & 0.00 \\
\hline Enough & 1 & 0.5 & 0 & 0 & 0 & 0 & 1 & 0.56 & \\
\hline Less & 0 & 0 & 0 & 0 & 0 & 0 & 0 & 0 & \\
\hline Total & 143 & 80.3 & 33 & 18.5 & 2 & 1.1 & 178 & 100 & \\
\hline
\end{tabular}

The result of protozoan infection affects the health of the body from mild levels that cause asymptomatic infections to severe levels in the form of cerebral malaria [23], [24]. The cycle of malaria transmission is influenced by human behavior as the host, which will then be easily transmitted if a new vector is suitable, Anopheles spp. mosquito. Community behavior in preventing mosquito bites will significantly affect the transmission of malaria. Prevention of mosquito bites will cut off the eye of the migratory vector to transmit protozoa from the host to other healthy individuals. This activity can take the form of environmental conditioning, such as the use of mosquito nets. The usage of mosquito net effectively overcomes the malaria burden worldwide [25], [26].

In this research, the respondent's level of knowledge about malaria and mosquito nets shows that the category is sufficient $(85.39 \%)$, about $7.87 \%$ less knowledge, and $6.74 \%$ good knowledge about malaria the use of mosquito nets. However, further analysis in this study shows no relationship between the level of knowledge and the behavior of using mosquito nets. Based on research, most respondents have a good family attitude about using mosquito nets (99.44\%), and only $0.56 \%$ of respondents have sufficient family attitudes on it, with a $p<0.05$, which means a relationship between attitude and behavior of using mosquito nets.

The behavior in using mosquito nets is supported by knowledge and other factors, such as experiences, habits, culture, and family economy. In this research, people in Ondorea Village, Nangapanda District, were using mosquito nets influenced mainly by the habit or culture within the families. Their daily habit already kept them from mosquito bites, which indirectly reduces the risk of malaria infection.

\section{Conclusion}

From the results of this study, it was concluded that the level of public knowledge in the moderate category was $85.39 \%$, those who had good knowledge were $6.34 \%$, and those who had moderate knowledge were $7.87 \%$. The public attitude about using mosquito nets is in a suitable category, namely $99.4 \%$, with a good attitude of $0.56 \%$. There is no relationship between the level of knowledge and the behavior of using mosquito nets, but it is found that there is a relationship between family attitudes and behavior using mosquito nets.

\section{References}

1. Kristina RH, Peni JA. Compliance of malaria drug intake and the using of bed nets of malaria patients in public health center of waipukang, Lembata district, East Nusa Tenggara in 2018. In: Proceeding $1^{\text {st }}$ International Conference Health Polytechnic 
of Kupang; 2018. p. 153-68. https://doi.org/10.26911/ theicph.2017.167

2. Aisyah RA, Susanna D. The use of insecticide-treated mosquito nets in children aged 0-4 years on the incidence of malaria. Kesmas Natl Public Health J. 2014;9(2):194. https://doi. org/10.21109/kesmas.v9i2.517

3. Hasyim H, Camelia A, Fajar NA. Determinants of Malaria Incidence in Endemic Areas. Kesmas Natl Public Health J. 2014;8(7):291. https://doi.org/10.21109/kesmas.v0i0.367

4. Ngambut K, Sila O. Environmental factors and community behavior about malaria in Kupang Timur sub-district, Kupang district. Kesmas Natl Public Health J. 2013;7(6):271. https://doi. org/10.21109/kesmas.v7i6.37

5. World Health Organization. Guidelines for The Treatment of Malaria. Vol. 21. Geneva, Switzerland: World Health Organization Press; 2009. p. 31-9.

6. NTT DP. Health Profile of East Nusa Tenggara Province; 2018. p. 1-146.

7. Badan Penelitian dan Pengembangan Kesehatan. Riset Kesehatan Dasar 2013, Riskesdas; 2013. p. 1-384.

8. Badan Penelitian dan Pengembangan Depkes RI. Riset Kesehatan Dasar Departemen Kesehatan Republik Indonesia. Indonesia: RiskesdasDepkes RI; 2007. https://doi.org/10.6066/ jtip.2013.24.2.121

9. World Health Organization. Malaria Case ManagementOperations Manual. Geneva, Switzerland: World Health Organization Press; 2009.

10. Kinansi RR. Artemisinin-based Combination of Antimalaria Therapy ( ACT ) in West Papua at 2013. Balaba. 2017;13(1):4354. https://doi.org/10.22435/blb.v13i1.255

11. Selasa P. Implementation of malaria elimination policy at Kupang City Public Health Center. J Info Kesehatan. 2017;15(1):97-109.

12. Kristina RH. Screening Test for Malaria Patients with Gold Standard Laboratory Tests for Validation of Positive Malaria Cases in the Lewoleba Health Center and Waipukang Health Center, Lembata Regency, East Nusa Tenggara Province in 2016. J Info Kesehatan. 2016;16(1):164-77. https://doi. org/10.22435/mpk.v24i2.3564.75-80

13. Resi EM. Effect of antimalaria herbal sambiloto (Andrographis paniculata Nees) on morphology changes of development and parasite Plasmodium falciparum. J Info Kesehatan. 2014;12:661-6

14. Faridah L, Albert C, Fauziah N. Effectiveness of various mosquito attractant solutions to control mosquito population Glob Med Health Commun. 2019;7:21-6. https://doi.org/10.29313/gmhc. v7i1.2974

15. Rangkuti AF, Sulistyani S, Endah WN. Environmental and Behavioral Factors Associated with Malaria Incidence in Panyabungan Mandailing Natal District, North Sumatra. Balaba J Litbang Pengendalian Penyakit Bersumber Binatang Banjarnegara. 2017;13(1):1-10. https://doi.org/10.22435/blb. v13i1.238
16. Kalangie F, Rombot DV, Kawatu PA. Factors Associated with Malaria Incidence in the Working Area of Touluaan Health Center, Southeast Minahasa Regency. J Med Kesehatan. 2013;7(3):1-7. https://doi.org/10.31227/osf.io/fk2qp

17. Ikawati B, Yunianto B, Djati AP. The Effectiveness of Using Insecticide Mosquito Nets in Malaria Endemic Villages in Wonosobo Regency. Balaba J Litbang Pengendalian Penyakit Bersumber Binatang Banjarnegara. 2010;6(2):1-6. https://doi. org/10.22435/blb.v14i1.290

18. World Health Organization. Assessment and Monitoring of Antimalarial Drug Efficacy for the Treatment of Uncomplicated Falciparum. Geneva, Switzerland: World Health Organization Press; 2003.

19. Ora AT, Widjanarko B, Udijono A. Perilaku ibu rumah tangga dalam menggunakan kelambu sebagai upaya pencegahan malaria di wilayah kerja puskesmas kabukarudi kabupaten sumba barat tahun 2014. J Promosi Kesehatan Indones. 2015;10(1):17-32. https://doi.org/10.14710/jpki.12.1.115-133

20. Mueller I, Zimmerman PA, Reeder JC. Plasmodium malariae and Plasmodium ovale-the 'bashful' malaria parasites. Trends Parasitol. 2007;23(6):278-83. https://doi.org/10.1016/j. pt.2007.04.009

PMid: 17459775

21. Loy DE, Liu W, Li Y, Learn GH, Plenderleith LJ, Sundararaman SA, et al. Out of Africa: Origins and evolution of the human malaria parasites Plasmodium falciparum and Plasmodium vivax. Int J Parasitol. 2017;47(2):87-97. https://doi. org/10.1016/j.ijpara.2016.05.008 PMid:27381764

22. Milner DA. Malaria pathogenesis. Cold Spring Harb Perspect Med. 2018;8(1):a025569. https://doi.org/10.1101/cshperspect. a025569

\section{PMid:28533315}

23. Dunst J, Kamena F, Matuschewski K. Cytokines and chemokines in cerebral malaria pathogenesis. Front Cell Infect Microbiol. 2017;7:324. https://doi.org/10.3389/fcimb.2017.00324 PMid:28775960

24. Idro $R$, Jenkins NE, Newton CR. Pathogenesis, clinical features, and neurological outcome of cerebral malaria. Lancet Neurol. 2005;4(12):827-40. https://doi.org/10.1016/ s1474-4422(05)70247-7

PMid:16297841

25. Guillet $P$, Alnwick D, Cham MK, Neira M, Zaim M, Heymann D, et al. Long-lasting treated mosquito nets: $\mathrm{A}$ breakthrough in malaria prevention. Bull World Health Organ. 2001;79(10):998. PMid:11693984

26. Eisele TP, Miller JM, Moonga HB, Hamainza B, Hutchinson P, Keating J. Malaria infection and anemia prevalence in Zambia's Luangwa district: An area of near-universal insecticide-treated mosquito net coverage. Am J Trop Med Hyg. 2011;84(1):152-7. https://doi.org/10.4269/ajtmh.2011.10-0287

PMid:21212219 